\title{
PENGARUH PUSAT KENDALI INTERNAL DAN EKSTERNAL, EFIKASI DIRI DAN KEPUASAN KERJA TERHADAP KOMITMEN KEORGANISASIAN KARYAWAN PADA PT. PASIFIK TEKNOLOGI INDONESIA
}

\author{
Desy Fitriani ${ }^{1)}$ dan Edi Purwanto ${ }^{2)^{*}}$ \\ ${ }^{1)}$ Program Studi Manajemen, Universitas Bunda Mulia \\ ${ }^{2)}$ Program Magister Manajemen, Universitas Bunda Mulia \\ Diterima 24/12/2018 / Disetujui 22/2/2019
}

\begin{abstract}
The purpose of this study was to examine the influence of internal locus of control, external locus of control, self-efficacy, and job satisfaction on organizational commitments. This research was conducted on employees of PT. Pacifik Teknologi Indonesia. The research used simple random sampling. Data collection was done by distributing questionnaires to 114 respondents. The result of the research shows that internal locus of control has a positive and significant effect on organizational commitment, external locus of control has a positive and significant effect on organizational commitment, then job satisfaction has a positive and significant effect on organizational commitment, but self-efficacy has not a positive and significant effect on organizational commitment. Simultaneously, internal locus of control, external locus of control, self-efficacy, and job satisfaction have a positive and significant effect on organizational commitment.
\end{abstract}

Keywords: internal locus of control, external locus of control, self efficacy, job satisfaction, organizational commitment.

\begin{abstract}
ABSTRAK
Tujuan penelitian ini adalah untuk menguji pengaruh pusat kendali internal, pusat kendali eksternal, efikasi diri, dan kepuasan kerja terhadap komitmen keorganisasian karyawan. Penelitian ini dilakukan pada karyawan PT. Pasifik Teknologi Indonesia. Metode pengambilan sampel menggunakan simple random sampling. Pengumpulan data dilakukan dengan menyebarkan kuesioner kepada 114 responden. Hasil penelitian menunjukkan bahwa pusat kendali internal berpengaruh positif dan signifikan terhadap komitmen keorganisasian, pusat kendali eksternal berpengaruh positif dan signifikan terhadap komitmen keorganisasian, kemudian kepuasan kerja berpengaruh positif dan signifikan terhadap komitmen keorganisasian, namun efikasi diri tidak berpengaruh positif dan signifikan terhadap komitmen keorganisasian. Secara simultan pusat kendali internal, pusat kendali eksternal, efikasi diri, dan kepuasan kerja berpengaruh positif dan signifikan terhadap komitmen organisasi.
\end{abstract}

Kata Kunci: Pusat kendali internal, pusat kendali eksternal, efikasi diri, kepuasan kerja, komitmen organisasi.

\footnotetext{
**Korespondensi Penulis: epurwanto@bundamulia.ac.id
} 


\section{PENDAHULUAN}

Sumber-sumber daya diperlukan oleh setiap organisasi atau perusahaan untuk mencapai tujuannya. Sumber-sumber daya merupakan sumber energi atau kekuatan yang diperlukan untuk menciptakan daya dan sumber-sumber daya tersebut meliputi sumber daya alam, sumber daya keuangan, sumber daya manusia, sumber daya ilmu pengetahuan, dan sumber daya teknologi. Di antara sumber-sumber daya tersebut, sumber daya yang paling penting adalah sumber daya manusia. Sumber daya manusia merupakan sumber daya yang digunakan untuk menggerakkan dan mensinergikan sumbersumber daya lainnya untuk mencapai tujuan organisasi. Tanpa sumber daya manusia, sumber-sumber daya lainnya kurang bermanfaat dalam mencapai tujuan organisasi (Wirawan, 2015).

Besarnya peranan sumber daya manusia dalam sebuah organisasi dikategorikan sebagai salah satu aset terpenting bagi perusahaan dalam upaya memperoleh keuntungan demi kelangsungan berdirinya sebuah organisasi. Mengingat pentingnya peran dan fungsi sumber daya manusia dalam pembentukan nilai tambah atas sumber daya organisasi, maka diperlukan pendayagunaan atas sumber daya secara efektif dan efisien (Mamik \& Syarif, 2016). Di dalam manajemen sumber daya manusia, komitmen keorganisasian merupakan salah satu topik yang paling banyak diteliti (Farrukh et al., 2017), karena komitmen seorang karyawan menjadi suatu hal yang sangat penting dan memiliki dampak yang besar pada keberhasilan kinerja suatu organisasi (Franco \& Franco, 2017). Komitmen organisasi merupakan derajat dimana seorang karyawan mengidentifikasikan dirinya dengan organisasi tertentu beserta tujuannya dan berkeinginan untuk mempertahankan keanggotaannya di dalam organisasi tertentu (Lampinen et al., 2017).

Komitmen organisasi yang tinggi ditemukan pada karyawan di salah satu perusahaan distributor kamera CCTV, PT. Pasifik Teknologi Indonesia. PT. Pasifik Teknologi Indonesia berdiri sejak tahun 2009 dan telah memiliki karyawan sebanyak 160 orang. Komitmen keorganisasian dari karyawan memiliki potensi mempengaruhi organisasi dan itu tercermin dalam absensi dan statistik pergantian (turnover) karyawan (Farrukh et al., 2017). Adapun data tentang absensi dan pergantian karyawan pada PT. Pasifik Teknologi Indonesia yaitu seperti pada Tabel 1.

Tabel 1 menunjukkan bahwa tingkat absensi karyawan di PT. Pasifik Teknologi Indonesia mengalami naik turun dalam periode Januari sampai dengan Desember 2015. Namun angka yang ditunjukkan tidak melebihi standar yang ditetapkan oleh perusahaan terhadap tingkat absensi karyawan perbulannya yaitu tidak boleh melebihi 20\%. Tabel 1 juga menunjukkan tingkat pergantian karyawan di PT. Pasifik Teknologi Indonesia pada tahun 2015 sebesar $-2,1 \%$. Jumlah karyawan yang keluar dalam periode Januari sampai dengan Desember 2015 lebih rendah ketimbang jumlah karyawan yang masuk. Walaupun standar tingkat pergantiankaryawan yang bisa ditolerir pada setiap perusahaan berbedabeda, namun menurut Harris \& Cameron (2005) jika tingkat pergantian mencapai lebih dari $10 \%$ per tahun maka dapat dikatakan bahwa tingkat pergantian karyawan tersebut tergolong tinggi. Tabel 1 menunjukkan indikasi bahwa karyawan pada PT. Pasifik Teknologi Indonesia memiliki komitmen yang tinggi terhadap perusahaan. 
Tabel 1 Tingkat Absensi dan Pergantian Karyawan

\begin{tabular}{ccccccc}
\hline $\begin{array}{c}\text { Periode } \\
2015\end{array}$ & $\begin{array}{c}\text { Jumlah } \\
\text { Karyawan } \\
\text { Awal }\end{array}$ & $\begin{array}{c}\text { Jumlah } \\
\text { Karyawan } \\
\text { Masuk }\end{array}$ & $\begin{array}{c}\text { Jumlah } \\
\text { Karyawan } \\
\text { Keluar }\end{array}$ & $\begin{array}{c}\text { Jumlah } \\
\text { Karyawan } \\
\text { Akhir }\end{array}$ & $\begin{array}{c}\text { Persentase } \\
\text { Absensi } \\
\text { Karyawan }\end{array}$ & $\begin{array}{c}\text { Persentase } \\
\text { Pergantian } \\
\text { Karyawan }\end{array}$ \\
Januari & 101 & 9 & 3 & 107 & $6 \%$ & $-5,77 \%$ \\
Februari & 107 & 6 & 7 & 106 & $5,6 \%$ & $0,94 \%$ \\
Maret & 106 & 8 & 5 & 109 & $6,6 \%$ & $-2,79 \%$ \\
April & 109 & 9 & 7 & 111 & $5,5 \%$ & $-1,81 \%$ \\
Mei & 111 & 5 & 5 & 111 & $6,3 \%$ & $0 \%$ \\
Juni & 111 & 9 & 3 & 117 & $5,4 \%$ & $-5,26 \%$ \\
Juli & 117 & 2 & 5 & 114 & $5,13 \%$ & $2,60 \%$ \\
Agustus & 114 & 5 & 11 & 108 & $6,14 \%$ & $5,41 \%$ \\
September & 108 & 20 & 6 & 122 & $5,56 \%$ & $-12,17 \%$ \\
Oktober & 122 & 12 & 8 & 126 & $4,92 \%$ & $-3,23 \%$ \\
November & 126 & 8 & 5 & 129 & $5,56 \%$ & $-2,35 \%$ \\
Desember & 129 & 10 & 9 & 130 & $4,65 \%$ & $-0,77 \%$
\end{tabular}

Pergantian Karyawan Tahun 2015 adalah -2,1\%

Absensi Karyawan Tahun 2015 adalah 5,61\%

Sumber:DataPT. Pasifik Teknologi Indonesia

Setelah melakukan pengamatan awal ke lapangan, diduga ada sejumlah faktor yang mempengaruhi komitmen keorganisasian karyawan di PT. Pasifik Teknologi Indonesia, yaitu pusat kendali internal dan eksternal, efikasi diri, dan kepuasan kerja. Sejumlah penelitian terdahulu juga telah membuktikan pengaruh faktor-faktor tersebut terhadap komitmen keorganisasian, misalnya, Nugrahaningsih et al. (2013) menunjukkan adanya pengaruh yang positif pusat kendali internal terhadap komitmen keorganisasian dan juga terdapat pengaruh yang positif pusat kendali eksternal terhadap komitmen keorganisasian. Pusat kendali adalah keyakinan individu terhadap mampu tidaknya mengontrol nasib mereka sendiri. Individu yang memiliki keyakinan bahwa nasib atau peristiwa-peristiwa dalam kehidupannya berada di bawah kontrol dirinya sendiri diartikan sebagai individu yang memiliki pusat kendali internal. Sementara itu, individu yang memiliki keyakinan bahwa lingkunganlah yang mempunyai kontrol terhadap nasib atau peristiwa-peristiwa yang terjadi dalam kehidupannya diartikan sebagai individu yang memiliki pusat kendali eksternal. Wangui (2015) juga menemukan pengaruh positif dan signifikan pusat kendali internal dan eksternal terhadap komitmen keorganisasian. Chhabra (2013) menemukan bahwa komitmen keorganisasianpara professional IT di India secara positif dan signifikan dipengaruhi oleh pusat kendali.

Faktor personal lainnya yang dapat mempengaruhi komitmen keorganisasian karyawan dalam perusahaan adalah efikasi diri (self efficacy). Efikasi diri merupakan keyakinan individu atas kapasitas ketrampilan, pengetahuan dan kemampuan mereka untuk menyelesaikan tugas dan memberikan kinerja terbaik mereka (Ahmed, 2018). Efikasi diri akan mempersiapkan individu dengan kemauan dan kemampuan untuk mengambil tantangan dan motivasi diri untuk berkembang dan unggul (Agu, 2015). Untuk mengembangkan komitmen keorganisasian karyawan, manajer harus mencoba untuk meningkatkan motivasi karyawan dalam melakukan tujuannya serta mengembangkan kesadaran bahwa mereka memiliki kemampuan untuk mencapai tujuan tersebut (Akhtar et al., 2013). Akhtar et al. (2013) menyatakan bahwa komitmen keorganisasian berhubungan positif dengan efikasi diri. Karyawan yang memiliki tingkat efikasi diri yang tinggi akan memiliki tingkat komitmen yang tinggi pula. Agarwal \& Mishra (2016) juga menemukan bahwa efikasi diri berpengaruh signifikan terhadap komitmen keorganisasian. Garcia (2015) juga menemukan bahwa efikasi diri memiliki 
pengaruh positif dan signifikan terhadap komitmen keorganisasian.

Komitmen terhadap organisasi juga dipengaruhi oleh faktor kepuasan kerja. Kepuasan kerja adalah apa yang setiap orang harapkan dari tempat mereka bekerja. Kepuasan kerja bersifat individual. Setiap individu akan memiliki tingkat kepuasan yang berbeda-beda tergantung pada nilai-nilai yang dipegang oleh setiap individu. Tingkat kepuasan yang dirasakan oleh setiap individu akan bergantung pada tingkat kesesuaian antara aspek dalam pekerjaan dengan keinginan individu. Chhabra (2013) menemukan bahwa kepuasan kerja karyawan berpengaruh secara positif dan signifikan terhadap komitmen keorganisasian para professional IT di India. Srivastava (2013) juga menemukan bahwa kepuasan kerja berpengaruh secara positif dan signifikan terhadap komitmen keorganisasian para manajer aras menengah di sejumlah perusahaan yang diteliti.

Berdasarkan pemaparan latar belakang di atas, maka berikut ini adalah hipotesishipotesis yang telah diuji: (1) Apakah terdapat pengaruh yang positif dan signifikan pusat kendali internal terhadap komitmen keorganisasian karyawan pada PT. Pasifik Teknologi Indonesia, (2) apakah terdapat pengaruh yang positif dan signifikan pusat kendali eksternal terhadap komitmen keorganisasian karyawan pada PT. Pasifik Teknologi Indonesia, (3) apakah terdapat pengaruh yang positif dan signifikan efikasi diri terhadap komitmen keorganisasian karyawan pada PT. Pasifik Teknologi Indonesia, (4) apakah terdapat pengaruh yang positif dan signifikan kepuasan kerja terhadap komitmen keorganisasian karyawan pada PT. Pasifik Teknologi Indonesia, dan (5) apakah terdapat pengaruh yang positif dan signifikan pusat kendali internal, pusat kendali eksternal, efikasi diri, dan kepuasan kerja secara simultan terhadap komitmen keorganisasian karyawan pada PT. Pasifik Teknologi Indonesia.

\section{Pusat Kendali}

\section{KAJIAN PUSTAKA}

Beberapa individu percaya bahwa mereka dapat mengendalikan apa yang terjadi pada diri mereka, sementara yang lain percaya bahwa apa yang terjadi pada diri mereka dikendalikan oleh kekuatan di luar diri mereka, seperti misalnya keberuntungan dan peluang. Pusat kendali (locus of control) mengeneralisasikan kepercayaan bahwa seseorang dapat atau tidak mengendalikan nasibnya sendiri (Syahputra, 2014). Locus of Control adalah konsep yang dikembangkan oleh Rotter pada tahun 1966. Rotter mengatakan bahwa individu-individu membangun harapan sukses mereka dalam situasi tertentu akan bergantung pada perilaku pribadi mereka atau dikendalikan oleh faktorfaktor di luar diri mereka sendiri (Srimindarti et al., 2015). Jadi, pusat kendali internal mengacu kepada kepercayaan individu bahwa mereka mampu mengendalikan kinerja mereka, sedangkan pusat kendali eksternal mengacu kepada kepercayaan individu bahwa kinerja mereka dikendalikan oleh lingkungan di luar diri mereka (Syahputra, 2014).

Individu-individu yang memiliki pusat kendali internal cenderung menghubungkan hasil dengan usaha-usaha mereka sendiri atau bahwa setiap kejadian berada di bawah kendali mereka. Sedangkan individu-individu yang percaya bahwa mereka tidak dapat mengendalikan setiap kejadian atau hasil yang mereka capai mengacu pada pusat kendali eksternal (Srimindarti et al., 2015). Orang dengan pusat kendali internal percaya bahwa mereka dapat memengaruhi lingkungan mereka dan bahwa tindakantindakan mereka berdampak pada apa yang terjadi pada diri mereka, sedangkan orangorang dengan pusat kendali eksternal percaya bahwa mereka memiliki sedikit pengaruh atas lingkungan dan apa yang terjadi pada mereka adalah karena faktor eksternal seperti keberuntungan, atau tindakan-tindakan orang lain (Munir, 2010).

\section{Efikasi Diri}

Konsep tentang efikasi diri pertama kali diusulkan oleh Bandura pada tahun 1977. Konsep ini mengacu pada kemampuan yang dirasakan seseorang untuk mengeksekusi tindakan-tindakan tertentu dengan penekanan pada bagaimana menunjukkan ketrampilan yang dimiliki seseorang ketimbang sekedar memiliki ketrampilan itu sendiri, dalam mencapai misi atau target yang diberikan kepadanya (Agu, 2015). Menurut Garcia 
(2015), efikasi diri mengacu pada keyakinan individu tentang kemampuannya untuk menyelesaikan tugasnya dengan berhasil. Efikasi diri adalah sebuah keyakinan bahwa seorang individu memiliki potensi untuk mencapai tujuan dengan mengelola situasi dan ini juga merupakan keyakinan tentang kemampuan seseorang untuk mencapai sukses (Zeb \& Nawaz, 2016). Agu (2015) menyatakan bahwa efikasi diri akan mempersiapkan individu dengan kemauan dan kemampuan untuk mengambil tantangan dan motivasi diri untuk berkembang dan unggul.

\section{Kepuasan Kerja}

Kepuasan kerja adalah sikap yang dimiliki seseorang terhadap pekerjaannya, atau dalam arti sederhana adalah bagaimana perasaan orang itu tentang pekerjaannya dan berbagai aspeknya (Saremi \& Rezeghi, 2015). Srivastava (2013) menjelaskan kepuasan kerja sebagai suatu perasaan positif terhadap pekerjaan. Menurut Spector, secara esensial kepuasan kerja dapat didefinisikan seberapa suka orang-orang itu terhadap pekerjaan mereka (Leite et al., 2014). Menurut Valaei \& Rezaei (2016), gagasan tentang kepuasan kerja itu kompleks dan itu tergantung pada aspek karakteristik manajer/karyawan dan budaya organisasi, dan oleh sebab itu,sulit untuk menilai dan mengukur tingkat kepuasan kerja, karena konsepnya adalah perilaku dan dapat dengan mudah dipengaruhi oleh beberapa faktor organisasi yang berasal dari lingkungan internal dan eksternal. Mengutip Spector et al., (2016) mendefinisikan kepuasan kerja sebagai keseluruhan dari perasaan individu atas pekerjaan dan sikap mereka terhadap aspekaspek dari pekerjaan mereka.

\section{Komitmen Keorganisasian}

Konsep komitmen keorganisasian didasarkan pada premis bahwa individu membentuk keterikatan pada organisasi (Srimindarti et al., 2015). Komitmen keorganisasian dapat didefinisikan sebagai kepercayaan individu kepada organisasi dan penerimaan mereka atas tujuan dan nilai-nilai perusahaan serta keinginan mereka untuk bertahan menjadi bagian dari keanggotaan organisasi tersebut (Syahputra, 2014).
Srimindarti et al. (2015) mendefinisikan komitmen organisasi sebagai kekuatan keterlibatan individu dalam suatu organisasi tertentu. Ada tiga faktor yang terlibat dalam komitmen keorganisasian, yaitu: kepercayaan dan penerimaan terhadap nilainilai dan tujuan-tujuan organisasi; (2) kesediaan untuk mengutamakan kepentingan organisasi; (3) dan keinginan kuat untuk tetap menjadi anggota organisasi (Srimindarti et al., 2015).

\section{Pengaruh Pusat Kendali Terhadap Komitmen Keorganisasian}

Komitmen keorganisasian yang lebih tinggi cenderung dimiliki oleh mereka yang memiliki pusat kendali internal karena mereka merasa bahwa mereka memiliki kendali atas lingkungan kerja mereka sendiri (Wangui, 2015). Nugrahaningsih et al. (2013) dalam penelitiannya tentang pengaruh pusat kendali internal dan eksternal yang dilakukan pada 108 dokter di RSUD Abdul Wahab Sjahranie Samarinda menyatakan bahwa pusat kendaliinternal berpengaruh positif terhadap komitmen organisasi dan pusat kendalieksternal juga berpengaruh positif terhadap komitmen organisasi. Chhabra (2013) menemukan bahwa pusat kendali secara positif dan signifikan berpengaruh terhadap komitmen keorganisasian. Berdasarkan teori dan penelitian terdahulu tersebut dapat dikembangkan dua hipotesis yang diteliti dalam penelitian ini, yaitu:

H1: Terdapat pengaruh yang positif pusat kendali internal terhadap komitmen keorganisasian.

H2: Terdapat pengaruh yang positif pusat kendali eksternal terhadap komitmen keorganisasian.

\section{Pengaruh Efikasi Diri Terhadap Komitmen Organisasi \\ Efikasi diri merupakan prediktor signifikan dari komitmen keorganisasian karena organisasi menuntut dan mencari karyawan yang memiliki keterampilan, kemampuan dan pengalaman kerja. Jika karyawan memiliki keterampilan yang baik dan kemampuannya relevan dengan pekerjaan}


mereka, maka akan membuat mereka yakin bahwa mereka bisa melakukan pekerjaan dengan baik. Seorang karyawan yang yakin dengan dirinya sendiri akan yakin juga bahwa ia mampu menyelesaikan pekerjaannya. Mereka akan memberikan kinerja yang baik serta menciptakan kepuasan kerja karena mereka merasa keberadaan dan karyanya dihargai dan menyebabkan mereka menjadi semakin komit dengan organisasi. Untuk mengembangkan komitmen keorganisasian karyawan, manajer harus mencoba untuk meningkatkan motivasi karyawan dalam melakukan tujuannya serta mengembangkan kesadaran bahwa mereka memiliki kemampuan untuk mencapai tujuan tersebut (Akhtar et al., 2013). Menurut Akhtar et al. (2013) komitmen keorganisasian berhubungan positif dengan efikasi diri. Ini menunjukkan bahwa efikasi diri dan komitmen organisasi mampu mempengaruhi satu sama lain. Hasil penelitian Akhtar et al. (2013) juga mengungkapkan bahwa karyawan yang memiliki tingkat komitmen yang tinggi pada umumnya adalah mereka yang memiliki tingkat efikasi diri yang tinggi.

Agarwal dan Mishra (2016) juga menemukan bahwa efikasi diri berpengaruh signifikan terhadap komitmen keorganisasian. Zeb \& Nawaz (2016) juga menemukan bahwa efikasi diri secara positif dan signifikan berpengaruh terhadap komitmen keorganisasian. Garcia (2015) juga menemukan bahwa efikasi diri terbukti memiliki pengaruh positif dan signifikan terhadap komitmen keorganisasian. Berdasarkan teori dan penelitian terdahulu tersebut juga dapat dikembangkan hipotesis ketiga yang diteliti dalam penelitian ini, yaitu:

H3: Terdapat pengaruh yang positif efikasi diri terhadap komitmen keorganisasian.

\section{Pengaruh Kepuasan Kerja Terhadap Komitmen Organisasi}

Srivastava (2013) menemukan bahwa kepuasan kerja terbukti memiliki pengaruh positif dan signifikan terhadap komitmen keorganisasian. Valaei \& Rezaei (2016) juga menemukan pengaruh kepuasan kerja terhadap komitmen keorganisasian para karyawan yang bekerja di sejumlah UKM Teknologi Informasi dan Komunikasi di Malaysia. Ćulibrk et al. (2018) juga menemukan pengaruh kepuasan kerja terhadap komitmen keorganisasian para karyawan di 8 perusahaan di Eropa Tenggara. Suma dan Lesha (2013) dalam penelitiannya yang dilakukan pada karyawan yang bekerja di sektor publik di Shkodra, Albania menemukan bahwa komitmen organisasi secara signifikan dan positif dipengaruhi oleh kepuasan kerja. Berdasarkan teori dan penelitian terdahulu tersebut dapat dikembangkan hipotesis keempat yang diteliti dalam penelitian ini, yaitu:

\section{H4: Terdapat pengaruh yang positif kepuasan kerja terhadap komitmen keorganisasian.}

Berdasarkan pengembangan hipotesishipotesis di atas dapat dibangun model penelitian yang diuji dalam penelitian ini (Gambar 1). 


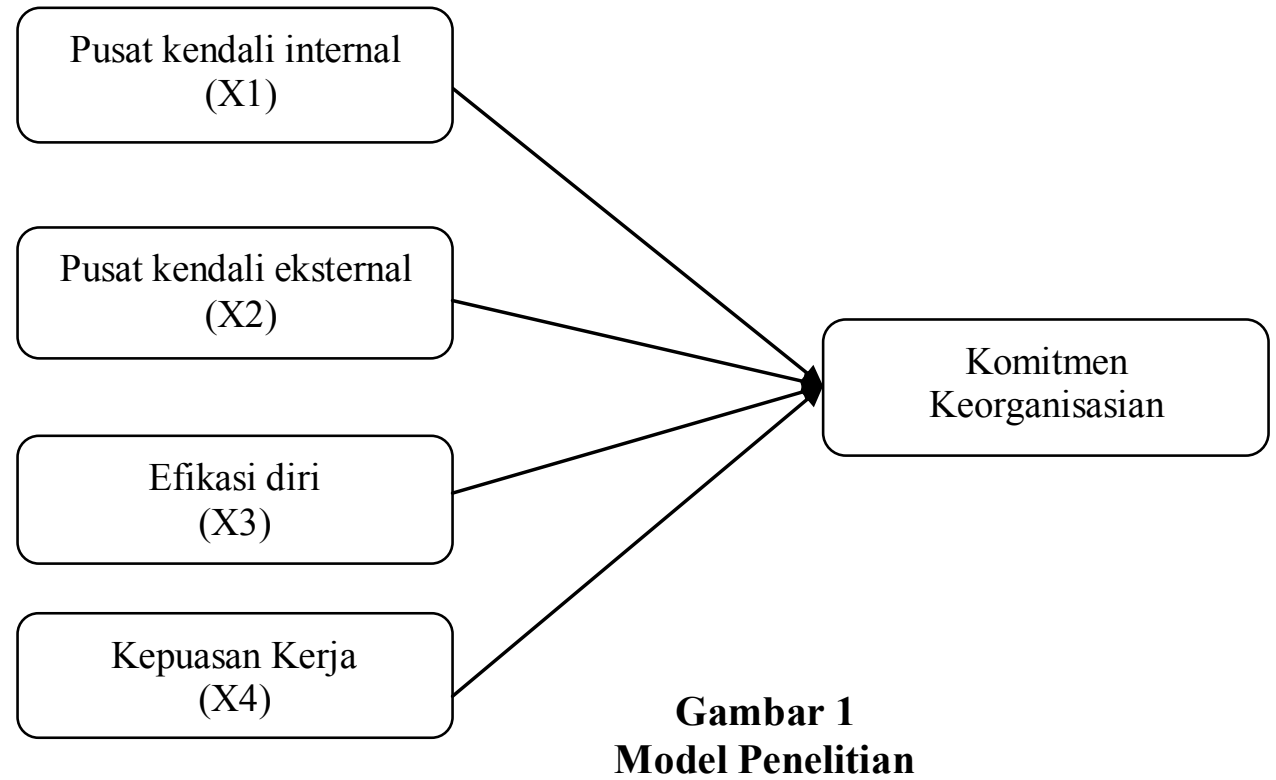

METODE PENELITIAN

Penelitian ini dilakukan di PT. Pasifik Teknologi Indonesia. Alasan memilih PT. Pasifik Teknologi Indonesia adalah karena menurut data, sebagaimana ditampilkan pada pendahuluan makalah ini, perusahaan ini memiliki tingkat absensi dan pergantian karyawan yang rendah. Rendahnya turnover menunjukkan tingginya komitmen keorganisasian karyawan pada perusahaan tersebut.

Populasi dalam penelitian ini adalah seluruh karyawan di PT. Pasifik Teknologi Indonesia yang berjumlah 160 orang yang terletak di Jalan Pangeran Jayakarta Kavling 123 No. 26/1 Jakarta Pusat. Pengambilan sampel dalam penelitian ini menggunakan rumus Slovin untuk menentukan minimal sampel yang dibutuhkan karena jumlah populasi sudah diketahui. Berikut perhitungan menggunakan rumus Slovin:

$$
\mathrm{n}=\frac{\mathrm{N}}{1+\mathrm{Ne}^{2}}
$$

Keterangan :

$$
\begin{aligned}
& \mathrm{n}: \text { Jumlah Sampel } \\
& \mathrm{N}: \text { Jumlah Populasi } \\
& \mathrm{e}: \text { Batas Toleransi Kesalahan (error } \\
& \text { tolerance) } \\
& \mathrm{n}=\frac{160}{1+(160)(0,05)^{2}} \\
& \quad=114 \text { Sampel }
\end{aligned}
$$

Dengan demikian dari 160 jumlah populasi diambil 114 sebagai sampel penelitian ini. Teknik sampling yang digunakan oleh penulis adalah simple random sampling (probability sampling). Probability sampling adalah teknik pengambilan sampel yang memberikan peluang yang sama untuk setiap anggota populasi untuk dapat dipilih menjadi anggota sampel. Dalam hal ini, para karyawan di PT. Pasifik Teknologi Indonesia akan penulis pilih secara acak sebagai sampel penelitian ini.

Skala pengukuran (measurement scales) untuk peubah pusat kendali internal dan pusat kendali eksternal diadaptasi dari Spector (1988). Peubah efikasi diri diukur dengan 10 butir instrumen yang dikembangkan oleh Schwarzer \& Jerusalem (1995). Peubah kepuasan kerja diukur menggunakan 11 butir instrumen yang dikembangkan oleh Cellucci \& Vries (1978). Kemudian peubah komitmen keorganisasian diukur dengan 21 butir instrumen yang dikembangkan oleh Allen \& Meyer (1990).

Pendekatan kuantitatif digunakan sebagai analisis penelitian ini dengan menguji hipotesis dengan metode analisis linear berganda. Pertama-tama dilakukan pengujian kesahihan dan kehandalan, kemudian dilakukan uji $t$ dan uji $F$. Hipotesis terbukti jika secara parsial menunjukkan hasil $\mathrm{t}$-value $>$ 1.96 (yang mana menurut Purwanto, 2016), 1.96 ini merupakan critical $t$-values for a 
twotailed test dengan tingkat kepercayaan 5 persen) dan sig. $<0.05$. Sedangkan untuk uji $\mathrm{F} \mathrm{F}_{\text {-hitung }}$ harus lebih besar dari $\mathrm{F}_{\text {-tabel. }}$ Untuk mencari nilai $\mathrm{F}_{\text {tabel }}$ dengan menggunakan tingkat keyakinan $95 \%, \alpha=5 \%$, df $1=(\mathrm{k}-1)$ atau $(5-1)=4$, dan df $2=(\mathrm{n}-\mathrm{k}-1)$ atau $114-5-1$ $=108$ ( $\mathrm{n}$ adalah jumlah sampel dan $\mathrm{k}$ adalah jumlah variabel), diperoleh hasil untuk $\mathrm{F}_{\text {-tabel }}$ sebesar 2,46.

\section{HASIL DAN PEMBAHASAN}

\section{Uji Validitas dan Reliabilitas}

Salah satu cara untuk melakukan uji kesahihan adalah dengan membandingkan nilai $\mathrm{r}_{\text {-hitung }}$ dengan $\mathrm{r}_{\text {-tabel. }}$ R-tabel untuk jumlah sampel 114, dengan $\mathrm{df}=112$ dan $\alpha=5 \%$ adalah 0,1840. Tabel 2-6 menunjukkan bahwa semua nilai r-hitung (Corrected Item-Total Correlation) lebih besar dari $\mathrm{r}_{\text {tabel. }}$ Dengan demikian dapat disimpulkan bahwa semua indikator dari semua peubah (peubah bebas maupun gayut) adalah sahih.

Tabel 2

Item-Total Statistics - Peubah Pusat Kendali Internal

\begin{tabular}{lrrrr}
\hline & $\begin{array}{c}\text { Scale Mean if Item } \\
\text { Deleted }\end{array}$ & $\begin{array}{c}\text { Scale Variance if Item } \\
\text { Deleted }\end{array}$ & $\begin{array}{c}\text { Corrected Item- } \\
\text { Total Correlation }\end{array}$ & $\begin{array}{c}\text { Cronbach's Alpha } \\
\text { if Item Deleted }\end{array}$ \\
\hline ILOC1 & 24.65 & 11.416 & .580 & .819 \\
ILOC2 & 24.92 & 11.295 & .623 & .811 \\
ILOC3 & 24.55 & 11.860 & .648 & .808 \\
ILOC4 & 24.61 & 12.310 & .518 & .827 \\
ILOC5 & 24.52 & 11.721 & .611 & .813 \\
ILOC6 & 24.58 & 11.980 & .621 & .812 \\
ILOC7 & 24.59 & 12.244 & .542 & .823 \\
\hline
\end{tabular}

Nilai $\mathrm{r}_{-}$-hitung (Corrected Item-Total Correlation) dari semua item peubah pusat kendali internal lebih besar dari $\mathrm{r}_{\text {-tabel }}$ (0.1840). Nilai $\mathrm{r}_{\text {-hitung }}$ ILOC1 adalah $0.580>$ 0,1840 , ILOC2 adalah $0.623>0.1840$, ILOC3 adalah 0,648 >0.1840, ILOC4 adalah
$0.518>0.1840$, ILOC5 adalah $0.611>$ 0.1840 , dan ILOC7 adalah $0.542>0.1840$, maka dapat disimpulkan bahwa semua indikator dari peubah pusat kendali internal adalah sahih. 


\section{Tabel 3}

Item-Total Statistics - Peubah Pusat Kendali Eksternal

\begin{tabular}{lrrrr}
\hline & $\begin{array}{c}\text { Scale Mean if Item } \\
\text { Deleted }\end{array}$ & $\begin{array}{c}\text { Scale Variance if Item } \\
\text { Deleted }\end{array}$ & $\begin{array}{c}\text { Corrected Item- } \\
\text { Total Correlation }\end{array}$ & $\begin{array}{c}\text { Cronbach's Alpha } \\
\text { if Item Deleted }\end{array}$ \\
\hline ELOC1 & 25.17 & 40.016 & .421 & .893 \\
ELOC2 & 25.55 & 37.541 & .670 & .874 \\
ELOC3 & 25.67 & 34.525 & .769 & .864 \\
ELOC4 & 25.62 & 35.706 & .765 & .865 \\
ELOC5 & 25.56 & 35.293 & .759 & .865 \\
ELOC6 & 25.24 & 39.775 & .475 & .889 \\
ELOC7 & 25.50 & 36.500 & .733 & .868 \\
ELOC8 & 25.15 & 40.447 & .468 & .888 \\
ELOC9 & 25.81 & 36.582 & .706 & .870 \\
\hline
\end{tabular}

Nilai $\mathrm{r}_{\text {-hitung }}$ (Corrected Item-Total Correlation) dari semua item peubah pusat kendali eksternal lebih besar dari $\mathrm{r}_{\text {tabel }}$ (0.1840). Nilai $\mathrm{r}_{-}$-hitung ELOC1 adalah 0.421> 0,1840 , ELOC2 adalah $0.670>0.1840$, ELOC3 adalah $0.769>0.1840$, ELOC4 adalah $0.765>0.1840$, ELOC5 adalah 0.759
$>0.1840$, ELOC6 adalah $0.475>0.1840$, ELOC7 adalah $0.733>0.1840$, ELOC8 adalah $0.468>0.1840$, dan ELOC9 adalah $0.706>0.1840$. Maka dapat disimpulkan bahwa semua indikator dari peubah pusat kendali ekesternal adalah sahih.

Tabel 4 Item-Total Statistics - Peubah Efikasi Diri

\begin{tabular}{lrrrr}
\hline & $\begin{array}{c}\text { Scale Mean if Item } \\
\text { Deleted }\end{array}$ & $\begin{array}{c}\text { Scale Variance if Item } \\
\text { Deleted }\end{array}$ & $\begin{array}{c}\text { Corrected Item- } \\
\text { Total Correlation }\end{array}$ & $\begin{array}{c}\text { Cronbach's Alpha } \\
\text { if Item Deleted }\end{array}$ \\
\hline SE1 & 34.75 & 13.390 & .531 & .817 \\
SE2 & 34.83 & 13.715 & .577 & .813 \\
SE3 & 35.10 & 13.238 & .536 & .817 \\
SE4 & 34.90 & 13.362 & .624 & .808 \\
SE5 & 35.03 & 13.318 & .567 & .813 \\
SE6 & 34.65 & 13.876 & .520 & .818 \\
SE7 & 34.89 & 13.890 & .454 & .825 \\
SE8 & 34.93 & 14.030 & .451 & .825 \\
SE9 & 34.89 & 13.989 & .513 & .819 \\
SE10 & 34.89 & 14.060 & .464 & .823 \\
\hline
\end{tabular}

Nilai r-hitung (Corrected Item-Total Correlation) dari semua item peubah efikasi diri lebih besar dari $\mathrm{r}_{\text {-tabel }}(0.1840)$. Nilai $\mathrm{r}$ hitung SE1 adalah $0.531>0,1840$, SE2 adalah $0.577>0.1840$, SE3 adalah $0.536>0.1840$,
SE4 adalah $0.624>0.1840$, SE5 adalah 0.567 $>0.1840$, SE6 adalah $0.520>0.1840$, SE7 adalah $0.454>0.1840$, SE8 adalah $0.451>$ 0.1840 , SE9 adalah $0.513>0.1840$, dan SE10 adalah $0.464>0.1840$. Maka dapat 
disimpulkan bahwa semua indikator dari peubah efikasi diri adalah sahih.

Tabel 5 Item-Total Statistics - Peubah Kepuasan Kerja

\begin{tabular}{lrrrr}
\hline & $\begin{array}{c}\text { Scale Mean if } \\
\text { Item Deleted }\end{array}$ & $\begin{array}{c}\text { Scale Variance if } \\
\text { Item Deleted }\end{array}$ & $\begin{array}{c}\text { Corrected } \\
\text { Item-Total } \\
\text { Correlation }\end{array}$ & $\begin{array}{c}\text { Cronbach's } \\
\text { Alpha if Item } \\
\text { Deleted }\end{array}$ \\
\hline KK1 & 35.89 & 25.836 & .419 & .851 \\
KK2 & 35.92 & 24.764 & .551 & .841 \\
KK3 & 35.95 & 24.050 & .568 & .840 \\
KK4 & 35.55 & 25.223 & .553 & .841 \\
KK5 & 35.60 & 25.376 & .511 & .844 \\
KK6 & 35.37 & 25.916 & .496 & .845 \\
KK7 & 35.71 & 25.411 & .467 & .848 \\
KK8 & 35.64 & 23.825 & .647 & .833 \\
KK9 & 35.75 & 23.713 & .626 & .835 \\
KK10 & 35.54 & 25.313 & .596 & .838 \\
KK11 & 35.55 & 25.577 & .536 & .842 \\
\hline
\end{tabular}

Nilai r-hitung (Corrected Item-Total Correlation) dari semua item peubah kepuasan kerja lebih besar dari $\mathrm{r}_{\text {-tabel }}(0.1840)$. Nilai - $_{\text {hitung }}$ KK1 adalah $0.419>0,1840$, KK2 adalah $0.551>0.1840$, KK3 adalah $0.568>$ 0.1840 , KK4 adalah $0.553>0.1840$, KK5 adalah $0.511>0.1840$, KK6 adalah $0.496>$
0.1840, KK7 adalah $0.467>0.1840$, KK 8 adalah $0.647>0.1840, \mathrm{KK} 9$ adalah $0.626>$ 0.1840 , KK10 adalah $0.596>0.1840$, dan KK11 $0.536>0.1840$. Maka dapat disimpulkan bahwa semua indikator dari peubah kepuasan kerja adalah sahih. 
Tabel 6 Item-Total Statistics - Peubah Komitmen Keorganisasian

\begin{tabular}{|c|c|c|c|c|}
\hline & $\begin{array}{c}\text { Scale Mean if Item } \\
\text { Deleted }\end{array}$ & $\begin{array}{c}\text { Scale Variance if Item } \\
\text { Deleted }\end{array}$ & $\begin{array}{l}\text { Corrected Item- } \\
\text { Total Correlation }\end{array}$ & $\begin{array}{l}\text { Cronbach's Alpha } \\
\text { if Item Deleted }\end{array}$ \\
\hline KO1 & 72.10 & 129.150 & .722 & .939 \\
\hline $\mathrm{KO} 2$ & 71.72 & 131.248 & .690 & .939 \\
\hline KO3 & 71.84 & 132.400 & .581 & .941 \\
\hline KO4 & 71.98 & 134.212 & .478 & .943 \\
\hline KO5 & 71.63 & 133.120 & .631 & .940 \\
\hline KO6 & 71.72 & 133.089 & .625 & .940 \\
\hline KO7 & 71.74 & 131.523 & .704 & .939 \\
\hline KO8 & 71.74 & 130.514 & .729 & .939 \\
\hline KO9 & 71.82 & 130.482 & .649 & .940 \\
\hline KO10 & 71.79 & 133.371 & .580 & .941 \\
\hline KO11 & 71.75 & 132.935 & .550 & .942 \\
\hline KO12 & 71.64 & 131.949 & .645 & .940 \\
\hline KO13 & 71.62 & 131.830 & .677 & .940 \\
\hline KO14 & 71.77 & 130.372 & .692 & .939 \\
\hline KO15 & 71.79 & 131.159 & .608 & .941 \\
\hline KO16 & 71.68 & 129.705 & .703 & .939 \\
\hline KO17 & 71.82 & 128.500 & .726 & .939 \\
\hline KO18 & 71.75 & 131.798 & .609 & .941 \\
\hline KO19 & 71.64 & 133.666 & .629 & .940 \\
\hline KO20 & 71.90 & 127.610 & .723 & .939 \\
\hline $\mathrm{KO} 21$ & 71.56 & 132.549 & .587 & .941 \\
\hline
\end{tabular}

Nilai $\mathrm{r}^{-}$hitung (Corrected Item-Total Correlation) dari semua item peubah komitmen keorganisasian lebih besar dari $\mathrm{r}$ tabel $(0.1840)$. Nilai $\mathrm{r}_{\text {-hitung }} \mathrm{KO}$ adalah $0.722>$ $0,1840, \mathrm{KO} 2$ adalah $0.690>0.1840, \mathrm{KO} 3$ adalah $0.581>0.1840, \mathrm{KO} 4$ adalah $0.478>$ 0.1840, KO5 adalah $0.631>0.1840$, KO6 adalah $0.625>0.1840, \mathrm{KO} 7$ adalah $0.704>$ $0.1840, \mathrm{KO} 8$ adalah $0.729>0.1840, \mathrm{KO} 9$ adalah $0.649>0.1840$, KO10 adalah $0.580>$ 0.1840 , dan KO11 $0.550>0.1840, \mathrm{KO} 12$ $0.645>0.1840, \mathrm{KO} 130.677>0.1840, \mathrm{KO} 14$ $0.692>0.1840, \mathrm{KO} 150.608>0.1840, \mathrm{KO} 16$ $0.703>0.1840$, KO17 $0.726>0.1840$, KO18 $0.609>0.1840, \mathrm{KO} 190.629>0.1840, \mathrm{KO} 20$ 22
$0.723>0.1840$, dan KO21 $0.587>0.1840$. Maka dapat disimpulkan bahwa semua indikator dari peubah komitmen keorganisasian adalah sahih.

Sedangkan salah satu cara untuk mengukur reliabilitas adalah dengan melihat nilai Cronbach's Alpha. Jika Cronbach's Alpha memiliki nilai di atas 0.60 maka peubah tersebut dikatakan reliabel. Tabel $7-$ 11 menunjukkan bahwa nilai Cronbach's Alpha dari semua variabel lebih besar dari 0.60 dan ini menunjukkan bahwa setiap variabel dinyatakan reliabel. 


\section{Tabel 7}

Reliability Statistics - Peubah Pusat Kendali Internal

\begin{tabular}{cc}
\hline Cronbach's Alpha & N of Items \\
\hline .838 & 7 \\
\hline
\end{tabular}

Tabel 7 menunjukkan bahwa nilai Cronbach's Alpha dari peubah pusat kendali internal lebih besar dari $0.60(0.838>0.60)$, sehingga dapat disimpulkan bahwa peubah pusat kendali internal dinyatakan reliabel.

\section{Tabel 8}

Reliability Statistics - Peubah Pusat Kendali Eksternal

\begin{tabular}{cc}
\hline Cronbach's Alpha & N of Items \\
\hline .888 & 9
\end{tabular}

Tabel 8 menunjukkan bahwa nilai Cronbach's Alpha dari peubah pusat kendali internal lebih besar dari $0.60(0.888>0.60)$, sehingga dapat disimpulkan bahwa peubah pusat kendali eksternal dinyatakan reliabel.

\section{Tabel 9}

Reliability Statistics - Peubah Efikasi Diri

Tabel 11 menunjukkan bahwa nilai Cronbach's Alpha dari peubah Komitmen Keorganisasian lebih besar dari 0.60 (0.943> 0.60 ), sehingga dapat disimpulkan bahwa peubah Komitmen Keorganisasian dinyatakan reliabel.

\section{Hasil Uji Hipotesis (Uji t)}

Mengacu pada Tabel 12, menunjukkan bahwa pusat kendali internal berpengaruh signifikan terhadap komitmen keorganisasian (H1), pusat kendali eksternal berpengaruh

\begin{tabular}{|c|c|}
\hline Cronbach's Alpha & $\mathrm{N}$ of Items \\
\hline 833 & 10 \\
\hline
\end{tabular}
Cronbach's Alpha dari peubah efikasi diri lebih besar dari $0.60(0.833>0.60)$, sehingga dapat disimpulkan bahwa peubah efikasi diri dinyatakan reliabel.

Tabel 10

Reliability Statistics - Peubah Kepuasan

\begin{tabular}{cc}
\multicolumn{2}{c}{ Kerja } \\
\hline Cronbach's Alpha & N of Items \\
\hline .854 & 11 \\
\hline
\end{tabular}

Tabel 10 menunjukkan bahwa nilai Cronbach's Alpha dari peubah kepuasan kerja lebih besar dari $0.60(0.854>0.60)$, sehingga dapat disimpulkan bahwa peubah kepuasan kerja dinyatakan reliabel.

\section{Tabel 11}

Reliability Statistics - Peubah Komitmen Keorganisasian

\begin{tabular}{cc}
\hline Cronbach's Alpha & N of Items \\
\hline .943 & 21 \\
\hline
\end{tabular}

signifikan terhadap komitmen keorganisasian (H2), dan kepuasan kerja berpengaruh signifikan terhadap komitmen keorganisasian (H4), namun efikasi diri tidak berpengaruh signifikan terhadap komitmen keorganisasian (H3). Hal tersebut dibuktikan dengan $\mathrm{t}_{\text {-value }}>$ 1.96. Sedangkan efikasi diri tidak terbukti mempengaruhi komitmen keorganisasian karyawan secara signifikan, hal tersebut ditunjukkan dengan $t_{- \text {value }}<1.96$. 


\begin{tabular}{|c|c|c|c|c|c|c|}
\hline \multicolumn{7}{|c|}{ Tabel 12 Hasil Uji t } \\
\hline \multirow{2}{*}{\multicolumn{2}{|c|}{ Model }} & Unstandardize & Coefficients & $\begin{array}{l}\text { Standardized } \\
\text { Coefficients }\end{array}$ & $\mathrm{t}$ & Sig. \\
\hline & & B & Std. Error & Beta & & \\
\hline & (Constant) & 5.112 & 9.181 & & .557 & .579 \\
\hline & TILOC & .496 & .243 & .163 & 2.042 & .044 \\
\hline \multirow[t]{3}{*}{1} & TELOC & .358 & .139 & .203 & 2.569 & .012 \\
\hline & TSE & .117 & .246 & .040 & .477 & .634 \\
\hline & TKK & 1.049 & .189 & .477 & 5.564 & .000 \\
\hline
\end{tabular}

Sumber : Hasil Pengolahan Data Dengan SPSS

\section{Hasil Uji F}

Tabel 13 menunjukkan bahwa terbukti terdapat pengaruh yang positif dan signifikan pusat kendali internal, pusat kendali eksternal, efikasi diri,dan kepuasan kerja secara simultan terhadap komitmen keorganisasian di antara karyawan pada PT. Pasifik Teknologi Indonesia menunjukkan bahwa $\mathrm{F}_{\text {-hitung }}>\mathrm{F}_{\text {tabel }}(22,383>2,46)$, maka terbukti adanya pengaruh yang positif dan signifikan pusat kendali internal, pusat kendali eksternal, efikasi diri, dan kepuasan kerja secara bersama-sama atau simultan terhadap komitmen keorganisasian karyawan pada PT. Pasifik Teknologi Indonesia.

Tabel 13

Hasil Uji F

\begin{tabular}{rlrrrrr}
\hline Model & & Sum of Squares & Df & Mean Square & F & Sig. \\
& Regression & 7366.072 & 4 & 1841.518 & 22.383 & $.000^{\mathrm{b}}$ \\
1 & Residual & 8967.893 & 109 & 82.274 & & \\
& Total & 16333.965 & 113 & & &
\end{tabular}

a. Dependent Variable: TKO

b. Predictors: (Constant), TKK, TILOC, TELOC, TSE

Sumber: Hasil Pengolahan Data Dengan SPSS 


\section{Pembahasan}

Hasil pengujian yang telah dilakukan mengenai pengaruh pusat kendali internal terhadap komitmen organisasi membuktikan terdapat pengaruh yang signifikan dengan nilai signifikansi $0,044<$ standar error 0,05 . Pusat kendali internal berpengaruh signifikan terhadap komitmen organisasi karyawan di PT. Pasifik Teknologi Indonesia karena mereka merasa bahwa keberhasilannya berkat usaha mereka sendiri. Hal ini menunjukkan pentingnya pusat kendali internal dalam meningkatkan komitmen organisasi karyawan di PT. Pasifik Teknologi Indonesia. Temuan ini mendukung penelitian Wangui (2015) bahwa mereka yang memiliki pusat kendali internal akan cenderung memiliki komitmen keorganisasian yang lebih tinggi karena mereka merasa bahwa mereka memiliki kendali atas lingkungan kerja mereka sendiri (Wangui, 2015). Seseorang dengan pusat kendali internalmemiliki pandangan yang positif terhadap pekerjaan dan organisasi mereka.

Hasil pengujian yang telah dilakukan mengenai pengaruh pusat kendali eksternal terhadap komitmen organisasi membuktikan terdapat pengaruh signifikan dengan nilai signifikansi $0,012<$ standar error 0,05 . Pusat kendali eksternal berpengaruh signifikan terhadap komitmen organisasi karyawan di PT. Pasifik Teknologi Indonesia karena mereka percaya bahwa peristiwa yang terjadi atas mereka di organisasi seperti promosi, kenaikan gaji, pujian, janji, dan pengembangan karier tidak ditentukan oleh tindakan dan perilaku mereka sendiri, tetapi oleh kekuatan eksternal. Hal ini menunjukkan pusat kendali eksternal juga penting dalam meningkatkan komitmen organisasi karyawan di PT. Pasifik Teknologi Indonesia. Temuan ini memperkuat temuan Nugrahaningsih et al. (2013) bahwa karyawan percaya bahwa peristiwa yang terjadi kepada mereka di organisasi juga dipengaruhi oleh kekuatan eksternal seperti kesempatan, keberuntungan, nasib atau orang lain yang memiliki pengaruh kuat dalam organisasi. Hasil penelitian ini juga menguatkan hasil penelitian Igbeneghu \& Popoola (2011).

Hasil pengujian yang telah dilakukan mengenai pengaruh efikasi diri terhadap komitmen organisasi membuktikan tidak terdapat pengaruh yang signifikan dengan nilai signifikansi $0,634>$ standar error 0,05 . Hal ini menunjukkan bahwa komitmen organisasi karyawan di PT. Pasifik Teknologi Indonesia tidak dipengaruhi oleh efikasi diri karena kurangnya proses adaptasi dan pembelajaran dalam situasi kerja yang terjadi di PT. Pasifik Teknologi Indonesia sehingga menyebabkan efikasi diri karyawan menjadi rendah. Lamanya seseorang bekerja pada suatu organisasi akan menentukan tingginya efikasi diri yang mereka miliki. Namun, tidak menutup kemungkinan bahwa efikasi diri yang dimiliki oleh individu tersebut bias saja cenderung menurun atau tetap. Tergantung pada bagaimana individu itu menghadapi keberhasilan dan kegagalan selama melakukan pekerjaan. Temuan ini tidak mendukung penelitian terdahulu Akhtar et al. (2013) yang menemukan bahwa efikasi diri berpengaruh signifikan terhadap komitmen organisasi.

Hasil uji pengaruh kepuasan kerja terhadap komitmen keorganisasian terbukti dengan nilai signifikansi $0,000<$ standar error 0,05 . Kepuasan kerja berpengaruh signifikan terhadap komitmen organisasi karyawan di PT. Pasifik Teknologi Indonesia karena perusahaan memberikan keadilan kepada seluruh karyawan dalam hal kesesuaian gaji. Karyawan merasa puas karena mereka menerima gaji sesuai dengan beban kerja. Kesesuaian gaji mengurangi persepsi karyawan akan kemungkinan bahwa pesaing memberikan gaji yang lebih baik dan berusaha untuk keluar dari organisasi. Hal ini menunjukkan pentingnya kepuasan kerja dalam meningkatkan komitmen organisasi karyawan di PT. Pasifik Teknologi Indonesia. Lincoln \& Kalleberg berasumsi bahwa kepuasan kerja merupakan penyebab komitmen organisasi (Suma \& Lesha, 2013).

Komitmen organisasi berkontribusi untuk sikap positif karyawan terhadap pekerjaan (Suma \& Lesha, 2013). Temuan ini sejalan dengan penelitian terdahulu dari Srivastava (2013) yang menemukan bahwa kepuasan kerja berpengaruh positif dan signifikan terhadap komitmen keorganisasian, juga Valaei dan Rezaei (2016) yang menemukan pengaruh kepuasan kerja terhadap komitmen keorganisasian para karyawan, dan Ćulibrk et al. (2018) yang 
juga membuktikan adanya pengaruh kepuasan kerja terhadap komitmen keorganisasian.

\section{SIMPULAN, KETERBATASAN DAN SARAN}

Hasil penelitian ini membuktikan bahwa pusat kendali internal berpengaruh positif dan signifikan terhadap komitmen keorganisasian. Hasil penelitian juga membuktikan bahwa pusat kendali eksternal berpengaruh positif dan signifikan terhadap komitmen keorganisasian. Kemudian hasil penelitian ini juga membuktikan bahwa kepuasan kerja berpengaruh positif dan signifikan terhadap komitmen keorganisasian karyawan. Namun demikian hasil penelitian ini tidak membuktikan bahwa efikasi diri berpengaruh positif dan signifikan terhadap komitmen keorganisasian. Namun hasil penelitian ini membuktikan bahwa pusat kendali internal, pusat kendali eksternal, efikasi diri, dan kepuasan kerja secara simultan berpengaruh positif dan signifikan terhadap komitmen keorganisasian.

Oleh karena pusat kendali internal dan eksternal terbukti berpengaruh terhadap komitmen keorganisasian karyawan, maka pada saat merekrut karyawan, pihak manajemen SDM perusahaan perlu mempertimbangkan faktor pusat kendali internal dan eksternal agar tujuan organisasi bisa terwujud. Pihak manajemen SDM perusahaan harus membuat kebijakan yang dapat meningkatkan tingkat kepuasan kerja karyawan. Misalnya, pemberian pelatihan rutin dan penyediaan pengembangan karier untuk karyawan karena hal ini dari waktu ke waktu tidak hanya membuat karyawan lebih kompeten tetapi juga akan meningkatkan kepuasan kerja mereka. Ini bisa lebih menyebabkan peningkatan komitmen keorganisasian mereka, karena terbukti dalam penelitian ini bahwa kepuasan kerja berpengaruh signifikan terhadap komitmen keorganisasian karyawan. Pada penelitian ini, sampel yang digunakan berjumlah 114 sampel. Diharapkan pada penelitian selanjutnya dapat memperluas atau mengambil sampel yang lebih besar dan dengan subjek penelitian yang berbeda.

\section{DAFTAR PUSTAKA}

Agarwal, S., \& Mishra, P. C. (2016). Self efficacy as predictor of organizational commitment among revenue personnel. The International Journal of Indian Psychology, 3(4), 3-5.

Agu, O. L. (2015). Work engagement, organizational commitment, self efficacy and organizational growth: A literature review. Information Impact: Journal of Information and Knowledge Management, 6(1), 14-29.

Ahmed, N. O. A. (2018). Career commitment the role of slef-efficacy, career satisfaction and organizational commitment. World Journal of Entrepreneurship, Management and Sustainable Development. https://doi.org/10.1108/JHOM-09-20160165

Akhtar, S., Ghayas, S., \& Adil, A. (2013). Self-efficacy and optimism as predictors of organizational commitment among bank employees. International Journal of Research Studies in Psychology, 2(2), 33-42.

https://doi.org/10.5861/ijrsp.2012.131

Allen, N. J., \& Meyer, J. P. (1990). The measurement and antecedents of affective, continuance and normative commitment to the organization. Journal of Occupational Psychology, 63(1), 1$18 . \quad$ https://doi.org/10.1111/j.20448325.1990.tb00506.x

Cellucci, A. J., \& Vries, D. L. De. (1978). Measuring managerial satisfaction: A manual for the MJSQ, Technical Report II.

Chhabra, B. (2013). Locus of control as a moderator in the relationship between job satisfaction and organizational commitment: A study in Indian IT professionals. Organizations and Markets in Emerging Economies., 4(2), 25-41.

Ćulibrk, J., Delić, M., Mitrović, S., \& Ćulibrk, D. (2018). Job satisfaction, organizational commitment and job 
involvement: The mediating role of job involvement. Frontiers in Psychology, 9(FEB).

https://doi.org/10.3389/fpsyg.2018.00132

Farrukh, M., Wei Ying, C., \& Mansori, S. (2017). Organizational commitment: an empirical analysis of personality traits for authors organizational commitment: an empirical analysis of personality traits. Journal of Work-Applied Management, 9(1), $18-34$. https://doi.org/10.1108/JWAM-12-20160026

Franco, M., \& Franco, S. (2017). Organizational commitment in family SMEs and its influence on contextual performance. Team Performance Management: An International Journal, 23(7/8), 364-384. https://doi.org/10.1108/TPM-05-20160020

Garcia, G. F. (2015). The Relationship between self-efficacy and employee commitment among perfusionists. Walden University.

Igbeneghu, Bruno I. and Popoola, S. O., "Influence of Locus of Control and Job Satisfaction on Organizational Commitment: A Study of Medical Records Personnel in University Teaching Hospitals in Nigeria" (2011). Library Philosophy and Practice (ejournal). 575.

Harris, G. E., \& Cameron, J. E. (2005). Multiple dimensions of organizational identification and commitment as predictors of turnover intentions and psychological well-being. Canadian Journal of Behavioural Science. https://doi.org/10.1037/h0087253

Lampinen, M.-S., Suutala, E., \& Konu, A. I. (2017). Sense of community, organizational commitment and quality of services. Leadership in Health Services, LHS-06-2016-0025. https://doi.org/10.1108/LHS-06-20160025

Leite, N. R. P., Rodrigues, A. C. de A., \& Albuquerque, L. G. (2014).
Organizational commitment and job satisfaction: What at the potential relationships? Brazilan Administration Review, 11(4), 476-495. https://doi.org/10.1590/18077692 bar2014276

Mamik \& Syarif, U. (2016). Manajemen sumber daya manusia. Sidoarjo: Zifatama Publisher.

Munir, S. (2010). Examining locus of control (LOC) as a determinant of organizational commitment among university professors in Pakistan. Journal of Business Studies Quarterly, 1(3), 78-93.

Nugrahaningsih, R., Noor, N. B., \& Rewa, S. (2013). Pengaruh pusat kendali internal dan eksternal terhadap komitmen organisasi dokter di RSUD Abdul Wahab Sjahranie Samarinda. Retrieved from http://pasca.unhas.ac.id/jurnal/files/ f69a8dd9e9cb71bc9a4195c3c755c8b9.pd $\mathrm{f}$

Purwanto, E. (2016). The effect of cosmopolitanism on perceived foreign product and purchase intentions: Indonesia case. Quality - Access to Success, 17(155).

Saremi, H., \& Rezeghi, A. A. (2015). A Study on the relationship between self-efficacy beliefs and organizational commitment with job satisfaction in office employees in Esfarayen city, Iran, 9(5), 91-94.

Schwarzer, R., \& Jerusalem, M. (1995). Generalized self-efficacy scale. In J. Weinman, S. Wright, \& M. Johnston. Measures in Health Psychology: A User's Portfolio. Causal and Control Beliefs, 35-37.

Spector, P. E. (1988). Development of the work locus of control scale. Journal of Occupational Psychology, 61(4), 335$340 . \quad$ https://doi.org/10.1111/j.20448325.1988.tb00470.x

Srimindarti, C., Sunarto, \& Widati, L. W. (2015). The effects of locus of control and organizational commitment to acceptance of dysfunctional audit behavior based on the theory of planned 
behavior. International Journal of Business, Economics and Law, 7(1), 2735 .

Srivastava, S. (2013). Job satisfaction and organizational commitment relationship: Effect of personality variables. Vision: The Journal of Business Perspective, 17(2), 159-167. https://doi.org/10.1177/09722629124835 29

Suma, S., \& Lesha, J. (2013). Job satisfaction and organizational commitment: The case of Shkodra Municipality. European Scientific Journal, 9(17), 1857-7881. https://doi.org/10.1108/MRR-09-20150216

Syahputra, Z. (2014). Influence of locus of control and organizational commitment on job satisfaction moderated by organizational culture and its impact on job performance (Study of employee's Aceh Local Government). Journal of Economics and Sustainable Development, 5(17), 104-111.

Valaei, N., \& Rezaei, S. (2016). Job satisfaction and organizational commitment: an empirical investigation among ICT-SMEs. Management Research Review, 39(12), 1663-1694. https://doi.org/10.1108/MRR-09-20150216

Wangui, W. P. (2015). The influence of locus of control on employee commitment and labour turnover: A case study of Jubilee Insurance Company Limited. University of Nairobi. Retrieved from http://erepository.uonbi.ac.ke/bitstream/h andle/11295/94457/Waweru_The influence of locus of control on employee commitment and labour turnover.pdf?sequence $=1$

Wirawan. (2015). Evaluasi kinerja sumber daya manusia. Jakarta: Salemba Empat.

Zeb, S., \& Nawaz, A. (2016). Impacts of selfefficacy on organizational commitment of academicians: A case of Gomal University, Dera Ismail Khan, Khyber, $6(1), 36-42$. 